\title{
PENGARUH FAKTOR SOSIAL EKONOMI, STRESSOR, DAN STRATEGI KOPING LANSIA TERHADAP STRES LANSIA SELAMA PANDEMI COVID-19
}

\author{
Diah Krisnatuti ${ }^{1 *}$, Eka Wulida Latifah ${ }^{1}$ \\ 1Departemen IImu Keluarga dan Konsumen, Fakultas Ekologi Manusia, \\ IPB University, Bogor 16880, Indonesia \\ *)E-mail: ekawulida87@gmail.com
}

\begin{abstract}
Abstrak
Lansia yang mengalami kondisi stres akan berdampak pada kualitas sumber saya manusia di Indonesia. Pandemi Covid-19 mengakibatkan beragam perubahan yang mengakibatkan munculnya stres, termasuk pada kelompok lanjut usia (lansia). Kondisi stres yang dialami oleh lansia dapat memengaruhi kualitas lansia di Indonesia. Penelitian ini bertujuan untuk menganalisis pengaruh karakteristik sosial ekonomi, stressor, strategi koping, dan praktek koping terhadap stres pada lansia selama masa pandemi. Penelitian ini menggunakan pendekatan kuantitiatif dengan desain cross sectional study yang melibatkan 210 responden berusia lansia. Pengolahan dan analisis data dilakukan secara deskriptif dan inferensial menggunakan uji tabulasi silang dan uji regresi. Responden perempuan dalam penelitian ini lebih banyak dibandingkan dengan responden laki-laki. Hasil penelitian menunjukkan bahwa lebih dari separuh responden berpendidikan tinggi yaitu tamat Perguruan Tinggi (PT). Lansia dalam penelitian ini mengalami tingkat stres dengan kategori yang rendah sebanyak 93,3 persen meskipun jumlah stres yang dialami akibat pandemi cukup banyak yakni sebanyak 22,9 persen. Stategi koping dan praktek koping yang dilakukan sudah sangat baik dilakukan oleh lansia dalam penelitian ini. Temuan menariknya adalah lansia yang menikah lebih banyak mengalami stres kategori tinggi. Hasil uji regresi juga menunjukkan bahwa faktor yang memengaruhi stres pada lansia secara signifikan selama masa pandemi ialah adalah usia, jenis kelamin, pendidikan, dan sumber stres. Hasil penelitian ini menyarankankan perlunya keterlibatan dan dukungan keluarga pada keluarga yang memiliki anggota keluarga berusia lansia.
\end{abstract}

Kata kunci: Covid-19, lansia, pandemi, stressor, stres

\section{The Effect of Social Economic Factors, Stressors and Elderly Coupling Strategies of Older Person Stress During The Covid-19 Pandemic}

\begin{abstract}
The stressfull conditions experienced by older person can affect quality of human resources in Indonesia. The Covid-19 pandemic has caused variety of changes that have resulted in stress including for older person. This study aims to analyze the influence of socio-economic characteristics, stressors, coping strategy, and practical coping on stress of the older person during pandemic. This study was used quantitavie approach with a crosssectional study design that involved 210 older person respondents. Processing and data analysis were carried out descriptively and inferential using cross-tabulation and regression tests. There were more female respondents than male respondents. Study shows more than half of the respondents have high education who graduated from university. Moreover, most respondents is the older person in this study experiencing a low level of stress not with standing the amount of stress experienced due to the pandemic is quite a lot. The coping strategies and coping practices carried out had been very well that implemented by the older person in this study. The regression test results also show that the factors that influence stress in the older person significantly during the pandemic were age, gender, education, and sources of stress. The results of this study suggested the need for family support in families with older person family members.
\end{abstract}

Keyword : Covid-19, mental health, pandemic, stressor, stress

\section{PENDAHULUAN}

Virus Covid-19 telah menjadi pandemi di dunia dengan jumlah peningkatan kasus dan jumlah kematian yang semakin bertambah cepat. Organisasi Kesehatan Dunia (WHO) mengakui tingkat keparahan Covid-19 dan menyatakannya sebagai pandemi global serta meminta setiap negara untuk mengambil tindakan secara tegas meliputi kebijakan karantina dan lockdown untuk menghambat penyebaran infeksi virus. World Health Organization (WHO) mencatat sebanyak 98.794.942 kasus terinfeksi Covid-19 yang terjadi di dunia dengan angka kematian mencapai 2.124.193 jiwa hingga 21 Januari 
2021. Indonesia sendiri menempati urutan ke-9 setelah India dari seluruh negara dengan jumlah terinfeksi sebanyak 989.262 jiwa dan jumlah kematian sebanyak 27.835 jiwa (WHO, 2021).

Pandemi Covid-19 mengakibatkan beragam perubahan yang belum pernah terjadi sebelumnya. Kebijakan yang telah ditetapkan dalam mengatasi krisis selama pandemi memengaruhi beragam sektor kehidupan manusia, diantaranya sektor kesehatan. Pandemi Covid-19 bukan hanya dapat memengaruhi kesehatan secara fisik, namun juga dapat memengaruhi masalah kesehatan mental. Kesehatan mental dapat dianggap sebagai bagian yang penting dan bisa dijadikan sebagai indikator keberhasilan dalam pembangunan sebuah negara. Hal ini dapat dilihat dalam salah satu poin pencapaian SDG's, yakni memastikan kehidupan dan yang sehat dan meningkatkan kesejahteraan untuk masyarakat dari beragam kalangan usia dengan target peningkatan kesehatan mental dan kesejahteraan masyarakat pada tahun 2030 mendatang (United Nation, 2020).

Beragamnya ketidakpastian dan ambiguitas yang terjadi secara kontinu menjadi penyebab munculnya masalah kesehatan mental selama pandemi berlangsung. Hasil riset menunjukkan bahwa selama pandemi terjadi peningkatan masalah stres, kecemasan dan depresi pada masyarakat (Wang et al., 2020). Berbagai gejala gangguan kesehatan mental juga dikaitkan dengan lebih banyaknya permasalahan dan gangguan pola tidur (Xiao, Zhang, Kong, Li, \& Yang, 2020). Pengurangan mobilitas dan ketidakberdayaan untuk berpartisipasi dalam kegiatan sosial dan budaya juga berdampak langsung pada kesehatan fisik dan kesehatan mental masyarakat (Santini et al., 2020). Pada studi kasus di Cina, pandemi berdampak besar pada kecemasan sosial yang dialami oleh masyarakat setelah diberlakukannya kebijakan lockdown (Lei et al., 2020).

Shanahan et al. (2020) mengungkapkan bahwa secara psikologis, pandemi merupakan peristiwa kehidupan yang terkait dengan ketidakpastian, ambiguitas, dan kehilangan kendali, yang masing-masing diketahui dapat memicu stres dan tekanan emosi. Pandemi yang mengakibatkan segala keterbatasan, disertai kekhawatiran tentang kesehatan seseorang dan orang yang dicintai, gangguan dan kerugian ekonomi, gangguan gaya hidup, isolasi sosial, dan kesepian, secara bersamaan dapat menciptakan badai dan tekanan emosi (Reger, Stanley, \& Joiner, 2020). Hasil survey daring Perhimpunan Dokter Spesialis Kedokteran Jiwa Indonesia (PDSKJI, 2020) terhadap 4.010 responden selama masa pandemi menunjukkan bahwa sebanyak 64,8 persen responden mengalami masalah psikologis, diantaranya kecemasan $(64,8 \%)$, depresi $(62 \%)$, dan trauma $(75 \%)$.

Salah satu kelompok usia yang rentan terdampak Covid-19 ialah kelompok usia lansia. Masalah psikologis terbanyak ditemukan pada kelompok usia lansia, yakni sebanyak 68,9 persen dari responden berusia lansia (PDSKJI, 2020). Virus Covid-19 berisiko khusus bagi kelompok usia lansia, terutama mereka yang mengidap multimorbiditas (Lai, PingShih, WenChien, Tang, \& Hsueh, 2020). Data dari KPCPEN (2020) menunjukkan bahwa jumlah terinfeksi Covid-19 pada kategori lansia di Indonesia per Juli 2020 mencapai angka 8.970 jiwa dengan jumlah kematian mencapai angka 1.423 jiwa atau setara dengan 15,93 persen dari yang terinfeksi. Kondisi ini dapat mengakibatkan masalah kesehatan mental pada populasi lansia sehingga dibutuhkan perhatian yang ekstra bagi mereka.

Stres yang terjadi di dalam keluarga dapat dijelaskan melalui model stress ABCX yang dicetuskan oleh Hill dan kemudian disempurnakan oleh McCubbin dan Patterson (Rosino, 2016). Model ini digunakan sebagai upaya untuk menganalisis faktor-faktor yang menentukan hubungan antara stres dan krisis dalam keluarga karena lansia merupakan bagian dari keluarga sehingga stress yang dialami keluarga akan berdampak kepada lansia. Variabel internal dalam model ini ialah (A) stresor atau situasi atau peristiwa stres dihadapi oleh sebuah keluarga, (B) sumber daya keluarga dalam bentuk kemampuan dalam mengatasi stres, dan (C) persepsi keluarga mengenai stress. Variabel eksternal (X) merujuk pada krisis yang terjadi di dalam keluarga yang nantinya akan mengarahkan kepada keberhasilan keluarga dalam menghadapi krisis.

Melalui model $A B C X$ dapat digambarkan bahwa pandemi yang terjadi saat ini menjadi krisis bagi keluarga. Hal ini ditunjukkan melalui hasil riset Plagg, Engl, Piccoliori, dan Eisendle (2020) yang menemukan bahwa kebiasaan sehari-hari pada lansia selama masa pandemi menjadi terbatas dan kondisi ini juga menjadi tantangan bagi mereka yang terbiasa dengan kemandirian dan aktivitas luar ruangan sebelum 
diberlakukannya kebijakan lockdwon. Kebijakan ini juga dapat mengakibatkan masalah gangguan sikap pada mereka yang berisiko yakni populasi lansia (Gerst-Emerson \& Jayawardhana, 2015). Kondisi pandemi juga mengakibatkan lansia mengalami gejala depresi, kesepian, pesimisme, kemunduran dalam kognisi, dan gangguan pola tidur (Buenaventura, Ho, \& Lapid, 2020). Hasil riset menunjukkan bahwa 37,1 persen lansia yang mengalami pandemi Covid-19 di China mengalami depresi dan kecemasan (Qiu et al., 2020). Lansia juga cenderung terpaku pada ketidakpastian selama pandemi dan merasakan kegelisahan (Huang \& Zhao, 2020).

Stres yang terjadi pada lansia, baik berupa gejala stres yang dialami dan sumber stres yang dimiliki dapat dipengaruhi oleh jumlah stres (stressor) yang dialami. Menurut Rosino (2016), stressor memengaruhi jumlah perubahan dan potensi stres yang membebani keluarga. Hasil riset lain juga menunjukkan bahwa sumber stres dapat memengaruhi stres pada seseorang (Mazo, 2015). Keluarga juga dapat mengurangi hal negatif sebagai efek dari stres dengan menggunakan sumber daya yang bisa membantunya menghindari krisis saat menghadapi stres (Rosino, 2016). Strategi koping merupakan sebagai bagian dari upaya mengurangi stres dalam keluarga yang berkontribusi terhadap tingkat stres seseorang. Puspitawati, Sarma, Herawati, Latifah, dan Moeljono (2013) menyatakan bahwa strategi koping merupakan berbagai perilaku baik yang terlihat maupun tidak terlihat yang dilakukan untuk mengurangi ketegangan yang dialami secara psikologis. Rosino (2016) juga menjelaskan bahwa strategi koping memiliki pengaruh terhadap tingkat stres seseorang.

Faktor sosial ekonomi secara umum juga dapat memengaruhi tingkat stres. Hasil penelitian Shanahan et al. (2020) dan Yovanoff (2011) menunjukkan bahwa jenis kelamin, tingkat pendidikan, dan pendapatan dapat memengaruhi tingkat stres. Muhammad, Muflikhati, dan Simanjuntak (2019) juga menemukan bahwa karakteristik individu dan keluarga memiliki pengaruh terhadap stres. Tidak hanya faktor sosial ekonomi, sumber stres juga dapat memengaruhi tingkat stres (Shanahan et al., 2020). Sejumlah penelitian lain juga membuktikan bahwa tingkat stres dipengaruhi oleh usia (Chen, Peng, Xu, \& OBrien, 2018; Lavretsky \& Newhouse, 2012; Panigrahi \& Dash, 2015; Seangpraw et al., 2019), jenis kelamin (Agrigoroaei, Lee-Attardo, \& Lachman, 2016; Girgus, Yang \& Ferri, 2017; Sacco, Bucholz, \& Harrington, 2013; Yan,
Dominguez, Fisher, \& Dong, 2018), pendidikan (Lunau, Siegrist, Dragano, \& Wahrendorf, 2015), dan pendapatan (Hjelm, Handa, Hoop, \& Palermo, 2017; Rimnacova \& Kajanova, 2019; Yahya, 2013).

Penelitian mengenai tingkat stres selama pandemi sudah banyak dilakukan, diantaranya penelitian yang mengaitkan pandemi dengan kesehatan sosial dan aktivitas rekreasi (Young \& Jeong, 2020), kecemasan sosial (Lei et al., 2020), serta kesehatan mental (Jing, Xing, Xiao, \& Van-ljzendoorn,2020; Jorge et al., 2020). Namun, penelitian pengaruh pandemi pada kategori usia lansia masih sedikit dilakukan. Beberapa diantaranya adalah Usman dan Fahy (2020) yang menganalisis koping lansia pada klinik psikiatri selama pandemi; Plagg, Engl, Piccoliori, dan Eisendle (2020) yang menganalisis kelebihan dan kekurangan isolasi sosial pada lansia di masa pandemi; dan Lyne, Roche, Kamali, dan Feeney (2020) yang mengevaluasi pelayanan kesehatan mental pada lansia di pedesaan dan perkotaan. Selama ini, belum ada penelitian mengenai faktor yang memengaruhi stres yang dialami selama masa pandemi secara spesifik pada lansia, khususnya di Indonesia. Penelitian sebelumnya juga tidak membahas secara mendalam mengenai pengaruh stategi koping terhadap stres yang dialami oleh lansia selama masa pandemi. Oleh karenanya, penelitian ini sangat penting untuk dilakukan sebagai upaya mengidentifikasi faktor-faktor yang dapat berpengaruh terhadap stres lansia semasa pandemi.

Oleh karenanya, mengingat pentingnya peningkatan kesehatan mental di kalangan lansia maka analisis stres pada lansia sangat diperlukan terutama untuk mendapatkan gambaran faktor apa saja yang memengaruhi stres pada lansia di Indonesia. Peneliti menguji hipotesis bahwa terdapat pengaruh karakteristik sosial ekonomi keluarga, sumber stres, strategi koping, dan praktek koping terhadap kondisi stres yang dialami lansia. Penelitian ini bertujuan untuk mengidentifikasi karakteristik sosial ekonomi, stressor, dan menganalisis pengaruh karakteristik sosial ekonomi, stressor, strategi koping, dan praktek koping terhadap stres pada lansia.

\section{METODE}

Penelitian ini dilakukan menggunakan desain cross sectional study, yaitu penelitian dilakukan pada satu waktu tertentu. Teknik pengambilan data diakukan dengan metode convenience sampling yang dilakukan secara daring dengan 
responden yang berasal dari wilayah yang beragam di Indonesia mulai dari 29 Oktober 25 November 2020. Kuesioner penelitian disebarkan melalui media whatsapp dan media sosial dengan mengisi platform google doc (http://bit.ly/KuesionerStresLansia).

Populasi penelitian ini adalah lansia dengan kategori usia 60 tahun ke atas sesuai dengan standar yang ditetapkan oleh WHO. Contoh dalam penelitian ini adalah lansia yang masuk kriteria penelitian dan bersedia mengisi survei daring. Pemilihan contoh dilakukan secara sengaja (accidental sampling). Total responden dalam penelitian ini adalah 210 responden. Data primer yang diambil dalam penelitian ini meliputi usia, jenis kelamin, kategori pendidikan, status pernikahan, status pekerjaan, sumber stres, strategi koping, dan praktek koping.

Sumber stres adalah suatu tindakan, keadaan, atau kejadian yang menjadi sebuah tuntutan bagi seseorang (Ivancevich, Konopaske, \& Matteson, 2005). Instrumen sumber stres terdiri atas sumber stres fisik dan psikis. Instrumen ini dinilai dengan delapan butir pernyataan yang dimodifikasi dari Oktarina, Muflikhati, dan Krisnatuti (2015) dengan menyesuaikan dengan kondisi yang dialami saat pandemi. Responden melaporkan frekuensi setiap jenis sumber stres pada skala 5 poin yakni $1=$ sangat tidak setuju, 2=tidak setuju, 3=tidak tahu, 4= setuju, dan $5=$ sangat setuju. Skor total berkisar dari 0 sampai 30 , yang bermakna skor yang lebih tinggi menunjukkan jumlah stres yang lebih banyak. Nilai Cronbach's alpha instrumen ini adalah 0,819. Skor variabel sumber stres dan dimensinya selanjutnya diubah menjadi indeks (0-100). Responden dibagi menjadi dua kategori, yakni sumber stres rendah dan tinggi dengan cut-off indeks 50. Untuk menentukan cut off dari variabel sumber stres, gejala stres, strategi koping, dan praktek koping diggunakan rumus interval kelas (Slamet, 1993).

Gejala stres merupakan tanda yang di alami seseorang apabila mengalami stres (Jovanovic, Lazaridis, \& Stefanovic, 2006). Namun dalam penelitian ini, peneliti memilih menggunakan instrumen lain yakni The Impact of Even Scale untuk menyesuaikan dengan kondisi pandemi. Instrumen gejala stres terdiri atas sumber stres fisik dan psikis Instrumen ini dinilai dengan 6 butir pernyataan yang dimodifikasi dari instrumen The Impact Even Scale (Weiss, 2007). Responden melaporkan frekuensi setiap jenis gejala pada skala 5 poin yakni $1=$ sangat tidak setuju, 2=tidak setuju, $3=$ tidak tahu, $4=$ setuju, dan $5=$ sangat setuju. Skor total berkisar dari 0 sampai 30 , yang bermakna skor yang lebih tinggi menunjukkan gejala stres yang lebih tinggi. Nilai Cronbach's alpha instrumen ini adalah 0,758. Variabel gejala stres dan dimensinya selanjutnya diubah menjadi indeks (0-100). Dengan cut-off indeks 50, responden dibagi menjadi dua kategori, yakni gejala stres rendah dan tinggi.

Strategi koping ialah usaha untuk beradaptasi yang dilakukan oleh seseorang saat menghadapi stres. Instrumen strategi koping terdiri atas strategi koping berfokus pada masalah (problem focused coping) dan strategi koping berfokus pada emosi (emotional focused coping) merujuk pada Oktarina, Muflikhati dan Krisnatuti (2015). Instrumen ini dinilai dengan delapan butir pernyataan yang dimodifikasi dari instrumen Simplified Coping Style Questionnaire (SCSQ) (Xie, 1998). Responden melaporkan frekuensi setiap jenis gejala pada skala 5 poin yakni $1=$ sangat tidak setuju, $2=$ tidak setuju, $3=$ tidak tahu, $4=$ setuju, dan $5=$ sangat setuju. Skor total berkisar dari 0 sampai 30, yang bermakna skor yang lebih tinggi menunjukkan strategi koping yang lebih banyak dilakukan. Nilai Cronbach's alpha instrumen ini adalah 0,702. Variabel strategi koping dan dimensinya selanjutnya diubah menjadi indeks (0-100). Dengan cut-off indeks 50, responden dibagi menjadi dua kategori, yakni strategi koping rendah dan tinggi.

Praktek koping ialah upaya adaptasi yang diakukan dalam menghadapi pandemi. Instrumen ini terdiri atas praktek koping yang dilakukan di dalam dan di luar rumah. Instrumen ini dinilai dengan delapan butir pernyataan yang dimodifikasi dari instrumen Practical Coping Behaviors with Covid-19 (Jing, Xing, Xiao, \& Van-ljzendoorn, 2020). Responden melaporkan frekuensi setiap jenis gejala pada skala 5 poin yakni $1=$ sangat tidak setuju, 2=tidak setuju, 3=tidak tahu, $4=$ setuju, dan $5=$ sangat setuju. Skor total berkisar dari 0 sampai 30 , yang bermakna skor yang lebih tinggi menunjukkan praktek koping yang lebih banyak dilakukan. Nilai alpha Cronbach instrumen ini adalah 0,871. Variabel praktek koping dan dimensinya selanjutnya diubah menjadi indeks (0-100). Dengan cut-off indeks 50 , responden dibagi menjadi dua kategori, yakni praktek koping rendah dan tinggi.

Sementara itu, usia dikelompokkan ke dalam tiga kategori yaitu lansia (60-74 tahun), lansia tua (75-90 tahun), dan lansia sangat tua (di atas 90 tahun). Tingkat pendapatan 
dikelompokkan menjadi tiga kategori yaitu rendah, sedang, dan tinggi. Tingkat pendidikan dikelompokkan menjadi tiga kategori yaitu rendah, sedang, dan tinggi. Status pernikahan dibagi ke dalam tiga kategori yakni kategori menikah, janda, dan duda. Status pekerjaan dibagi ke dalam tiga kategori yakni bekerja, tidak bekerja, dan pensiun.

Analisis data yang digunakan dalam penelitian ini ialah analisis deskriptif dan inferensial. Analisis tersebut dilakukan menggunakan alat bantu SPSS. Untuk mengetahui sebaran jawaban dilakukan analisis deskriptif. Analisis inferensial yang digunakan adalah uji regresi linear berganda. Uji regresi dilakukan untuk menganalisis pengaruh karakteristik responden (usia, jenis kelamin, kategori pendidikan, status pernikahan, kategori pendapatan), sumber stres, strategi koping, dan praktek koping terhadap stres lansia.

\section{HASIL}

\section{Karakteristik Sosial Ekonomi Responden}

Jenis Kelamin. Proporsi responden berdasarkan jenis kelamin menunjukkan bahwa responden perempuan lebih banyak dibandingkan dengan responden laki-laki. Hasil penelitian menunjukkan bahwa hampir 90 persen responden memiliki usia yang menyebar pada kategori lanjut usia (60-74 tahun) dengan persentase sebanyak 86,2 persen dengan ratarata usia 66,8 tahun. Responden yang berusia lansia sangat tua (> 90 tahun) terdiri atas 0,5 persen.

Status Pernikahan. Sebagian besar responden memiliki status menikah (64,8\%) dan kurang dari empat puluh persen responden memiliki status janda dan duda. Hal ini menunjukkan bahwa status pernikahan responden bervariasi.

Pendidikan. Hasil penelitian menunjukkan bahwa lebih dari setengah responden $(54,8 \%)$ memiliki kategori pendidikan tamat Perguran Tinggi. Sementara itu, lebih dari 30 persen responden berpendidikan terakhir SMP dan SMA. Hasil lain juga menunjukkan bahwa masih ada 6,2 persen responden yang tidak bersekolah dan sekitar 18,6 persen adalah lulusan SD.

Status Pekerjaan. Status pekerjaan responden bervariasi mulai dari responden yang tidak bekerja, bekerja, dan pensiun. Menariknya, responden keluarga yang bekerja, tidak bekerja dan pensiun tidak jauh berbeda proporsinya.
Tabel 1 Sebaran responden dan rata-rata indeks berdasarkan kategori dimensi variabel sumber stress (persen)

\begin{tabular}{lllc}
\hline \multicolumn{1}{c}{ Variabel } & \multicolumn{1}{c}{ Kategori } & $\mathrm{n}$ & $\%$ \\
\hline $\begin{array}{l}\text { Sumber } \\
\text { stres fisik }\end{array}$ & $\begin{array}{l}\text { Indeks } \leq 50 \\
\text { (rendah) } \\
\text { Indeks }>50\end{array}$ & 146 & 69,5 \\
& $\begin{array}{l}\text { (tinggi) } \\
\text { Minimum- } \\
\text { maksimum indeks }\end{array}$ & $040-100,0$ & 30,5 \\
& Rata-rata indeks & $41,3 \pm 23,3$ \\
\hline $\begin{array}{l}\text { Sumber } \\
\text { stres psikis }\end{array}$ & $\begin{array}{l}\text { Indeks } \leq 50 \\
\text { (rendah) }\end{array}$ & 164 & 78,1 \\
& $\begin{array}{l}\text { Indeks }>50 \\
\text { (tinggi) }\end{array}$ & 46 & 21,9 \\
& $\begin{array}{l}\text { Minimum- } \\
\text { maksimum indeks }\end{array}$ & $0,0-90,0$ \\
& $\begin{array}{l}\text { Rata-rata indeks } \\
\text { Sumber }\end{array}$ & $\begin{array}{l}\text { Indeks } \leq 50 \\
\text { (sedikit) }\end{array}$ & $162,1 \pm 18,6$ \\
\hline stres total & $\begin{array}{l}\text { Indeks }>50 \\
\text { (banyak) }\end{array}$ & 48,1 \\
& $\begin{array}{l}\text { Minimum- } \\
\text { maksimum indeks }\end{array}$ & $0,0-93,8$ \\
& Rata-rata indeks & $40,7 \pm 18,9$ \\
\hline
\end{tabular}

Keterangan: $\mathrm{n}=$ Jumlah responden; \%=persen

Responden yang tidak bekerja sedikit lebih tinggi dari yang bekerja, hanya berbeda sembilan persen, sementara responden yang pensiunan sedikit lebih tinggi dari yang tidak bekerja, hanya berbeda tujuh persen.

Pendapatan. Pendapatan dalam penelitian ini merupakan pendapatan yang dihasilkan dari sumber pendapatan utama dan pendapatan tambahan. Penelitian menunjukkan bahwa lebih dari tiga puluh persen $(35,7 \%)$ memiliki pendapatan di bawah Rp1.000.000,00 per bulannya. Sementara itu, hampir tiga puluh persennya memiliki pendapatan di atas $\mathrm{Rp}$ $5.000 .000,00$ per bulannya dan hampir empat puluh persen responden memiliki pendapatan antara 1-5 juta per bulannya.

\section{Sumber Stres}

Sumber stres lansia dinilai dari sumber stres yang dialami lansia semasa pandemi. Hasil pada Tabel 1 menunjukkan bahwa lebih dari dua puluh persen $(22,9 \%)$ responden memiliki jumlah stres yang banyak dan lebih dari separuh responden $(77,1 \%)$ memiliki jumlah stres yang sedikit. Selanjutnya, rata-rata indeks jumlah sumber stres pada responden adalah 40,7. Hal ini membuktikan bahwa responden memiliki jumlah stres dengan kategori cukup banyak. 
Tabel 2 Sebaran responden dan rata-rata indeks berdasarkan kategori dimensi variabel gejala stress (persen)

\begin{tabular}{|c|c|c|c|}
\hline Variabel & Kategori & $\mathrm{n}$ & $\%$ \\
\hline \multirow[t]{4}{*}{$\begin{array}{l}\text { Gejala } \\
\text { fisik }\end{array}$} & $\begin{array}{l}\text { Indeks } \leq 50 \\
\text { (rendah) }\end{array}$ & 190 & 90,5 \\
\hline & $\begin{array}{l}\text { Indeks > } 50 \\
\text { (tinggi) }\end{array}$ & 20 & 9,5 \\
\hline & $\begin{array}{l}\text { Minimum- } \\
\text { maksimum indeks }\end{array}$ & \multicolumn{2}{|c|}{$0,0-83,0$} \\
\hline & Rata-rata indeks & \multicolumn{2}{|c|}{28,8} \\
\hline \multirow[t]{4}{*}{$\begin{array}{l}\text { Gejala } \\
\text { psikis }\end{array}$} & $\begin{array}{l}\text { Indeks } \leq 50 \\
\text { (rendah) }\end{array}$ & 194 & 92,4 \\
\hline & $\begin{array}{l}\text { Indeks }>50 \\
\text { (tinggi) }\end{array}$ & 16 & 7,6 \\
\hline & $\begin{array}{l}\text { Minimum- } \\
\text { maksimum indeks }\end{array}$ & \multicolumn{2}{|c|}{$0,0-75,0$} \\
\hline & Rata-rata indeks & \multicolumn{2}{|c|}{28,7} \\
\hline \multirow[t]{4}{*}{$\begin{array}{l}\text { Gejala } \\
\text { stres }\end{array}$} & $\begin{array}{l}\text { Indeks } \leq 50 \\
\text { (rendah) }\end{array}$ & 196 & 93,3 \\
\hline & $\begin{array}{l}\text { Indeks }>50 \\
\text { (tinggi) }\end{array}$ & 14 & 6,7 \\
\hline & $\begin{array}{l}\text { Minimum- } \\
\text { maksimum indeks }\end{array}$ & \multicolumn{2}{|c|}{$0,0-72,0$} \\
\hline & Rata-rata indeks & \multicolumn{2}{|c|}{27,8} \\
\hline
\end{tabular}

Sumber Stres Fisik. Hasil penelitian menunjukkan bahwa responden merasa tidak bisa bersilaturahmi dengan teman-teman dan merasa sedih karna pendapatan berkurang. Pandemi juga menjadikan kondisi lansia mengalami keterbatasan untuk bisa beraktivitas di luar rumah sehingga menjadi sumber stres bagi mereka. Keberadaan Covid-19 memang menjadikan lansia menjadi lebih berhati-hati dengan kondisi kesehatannya. Responden juga merasakan pendapatannya berkurang bahkan tidak memiliki uang selama pandemi.

Sumber Stres Psikis. Responden juga menyatakan bahwa mereka merasakan ketakutan tertular Covid-19 dan sering merasa rindu untuk bertemu dengan anak cucu. Para lansia dalam penelitian ini juga harus menahan rasa rindu kepada anggota keluarga yang jauh dari jangkauan karena kebijakan PSBB (Pembatasan Sosial Berskala Besar) semasa pandemi. Responden merasa kesal dan bosan karena harus diam di rumah. Responden juga merasa kesepian, merasa ada beban berat di dalam dirinya serta merasa putus asa dalam menghadapi berbagai masalah.

\section{Gejala Stres}

Berdasarkan gejala stres, hampir sepersepuluh responden dalam penelitian ini mengalami tingkat stres yang tinggi $(6,7 \%)$ dan sebagian besar responden mengalami tingkat stres yang rendah $(93,3 \%)$. Temuan ini diperkuat dengan pencapaian rata-rata indeks stres lansia yang hanya mencapai angka 27,8. Hal ini menunjukkan bahwa responden merasa sumber daya yang dimiliki membuatnya masih mampu menghadapi stres yang dialami meskipun pandemi menghantam. Selain itu, status pendidikan sebagian lansia dalam penelitian ini yang termasuk ke dalam kategori tinggi juga diduga berkontribusi terhadap kondisi stres yang dialami lansia (Tabel 2).

Gejala Fisik. Responden merasakan bahwa dengan mengingat Covid-19 menyebabkan mereka mengalami reaksi fisik (seperti berkeringat, kesulitan bernapas, mual atau jantung berdebar kencang, sakit perut). Responden juga merasakan kesulitan untuk tidur dan mudah terkejut. Pemberitaan di media yang menunjukkan terjadinya peningkatan jumlah pasien Covid-19 memungkinkan para lansia untuk mengalami reaksi fisik.

Gejala Psikis. Gejala psikis yang paling banyak dirasakan oleh responden yaitu bermimpi tentang Covid-19. Kondisi pandemi ini diduga menimbulkan kekhawatiran yang mendalam pada diri lansia. Selain itu, responden juga merasakan kesendirian akibat pandemi dan memikirkan Covid-19 meskipun tidak bermaksud untuk memikirkannya.

\section{Stategi Koping}

Stategi koping dilihat dari seberapa banyak strategi yang dilakukan oleh lansia dalam menghadapi masalah pandemi. Hasil pada Tabel 3 menunjukkan bahwa hampir seluruh $(95,1 \%)$ responden melakukan strategi koping dengan kategori tinggi dan kurang dari lima persen responden $(4,9 \%)$ melakukan strategi koping dengan kategori rendah. Selanjutnya, rata-rata indeks jumlah sumber stres pada responden adalah 74,5. Hal ini menunjukkan bahwa responden dalam penelitian ini melakukan strategi koping dengan cukup baik.

Strategi Berfokus Masalah. Selama pandemi, lansia melakukan strategi dengan memperbaiki komunikasi dengan orang yang tinggal serumah. Komunikasi yang diperbaiki menjadi cara yang efektif yang dilakukan oleh lansia dalam menghadapi masa pandemi. Lansia juga berusaha mencari informasi tentang tentang pencegahan penularan Covid-19 dan pengalaman pasien yang berhasil sembuh dari Covid-19. Hal ini dilakukan agar lansia bisa mempelajari cara-cara yang dilakukan oleh 
pasien yang berhasil sembuh dan mengikuti langkah-langkah yang dilakukan.

Strategi Berfokus Emosi. Salah satu strategi yang dilakukan responden dalam penelitian ini adalah menjalankan ibadah dengan khusyuk. Hal tersebut dilakukan untuk mendapatkan ketenangan selama masa pandemi sehingga menjadi cara yang efektif dalam menghadapi stres. Responden juga mencoba untuk melihat sisi baik dan mengambil hikmah dari kejadian pandemi Covid-19 serta melakukan hobi untuk mengisi waktu. Mereka juga menghibur diri sendiri dengan melakukan sesuatu yang menyenangkan (Tabel 3).

\section{Praktek Koping}

Praktek koping dilihat dari seberapa banyak praktek berkaitan dengan protokol kesehatan yang dilakukan oleh lansia selama masa pandemi. Tabel 4 menunjukkan bahwa hampir seluruh $(93,3 \%)$ responden melakukan praktek koping dengan kategori tinggi dan kurang dari sepuluh persen responden $(6,7 \%)$ melakukan praktek koping dengan kategori rendah. Selanjutnya, rata-rata indeks jumlah sumber stres pada responden adalah 78,3 . Temuan ini mengemukakan bahwa responden melakukan strategi koping dengan cukup baik.

Praktek Koping di dalam Rumah. Selama pandemi, lansia sering mencuci tangan menggunakan sabun. Menurut lansia, mencuci tangan dengan sabun merupakan salah satu cara yang paling efektif dan mudah dilakukan oleh lansia semasa pandemi.

Tabel 3 Sebaran responden dan rata-rata indeks berdasarkan kategori dimensi variabel strategi koping (persen)

\begin{tabular}{|c|c|c|c|}
\hline Variabel & Kategori & $\mathrm{n}$ & $\%$ \\
\hline \multirow{4}{*}{$\begin{array}{l}\text { Strategi } \\
\text { berfokus } \\
\text { masalah }\end{array}$} & Indeks $\leq 50$ (rendah) & 26 & 12,4 \\
\hline & Indeks > 50 (tinggi) & 184 & 87,6 \\
\hline & $\begin{array}{l}\text { Minimum-maksimum } \\
\text { indeks }\end{array}$ & \multicolumn{2}{|c|}{$0,0-100,0$} \\
\hline & Rata-rata indeks & \multicolumn{2}{|c|}{71,3} \\
\hline \multirow{4}{*}{$\begin{array}{l}\text { Strategi } \\
\text { berfokus } \\
\text { emosi }\end{array}$} & Indeks $\leq 50$ (rendah) & 74 & 35,2 \\
\hline & Indeks > 50 (tinggi) & 136 & 64,8 \\
\hline & $\begin{array}{l}\text { Minimum-maksimum } \\
\text { indeks }\end{array}$ & \multicolumn{2}{|c|}{$25,0-75,0$} \\
\hline & Rata-rata indeks & \multicolumn{2}{|c|}{55,3} \\
\hline \multirow{4}{*}{$\begin{array}{l}\text { Strategi } \\
\text { koping }\end{array}$} & Indeks $\leq 50$ (rendah) & 10 & 4,9 \\
\hline & Indeks > 50 (tinggi) & 200 & 95,1 \\
\hline & $\begin{array}{l}\text { Minimum-maksimum } \\
\text { indeks }\end{array}$ & \multicolumn{2}{|c|}{$37,5-100,0$} \\
\hline & Rata-rata indeks & \multicolumn{2}{|c|}{73,7} \\
\hline
\end{tabular}

Keterangan: $n=J u m l a h$ responden; \%=persen
Tabel 4 Sebaran responden dan rata-rata indeks berdasarkan kategori dimensi variabel praktek koping (persen)

\begin{tabular}{|c|c|c|c|}
\hline Variabel & Kategori & $\mathrm{n}$ & $\%$ \\
\hline \multirow{4}{*}{$\begin{array}{l}\text { Praktek } \\
\text { di } \\
\text { dalam } \\
\text { rumah }\end{array}$} & Indeks $\leq 50$ (rendah) & 15 & 7,1 \\
\hline & Indeks > 50 (tinggi) & $\begin{array}{l}19 \\
5\end{array}$ & 92,9 \\
\hline & $\begin{array}{l}\text { Minimum-maksimum } \\
\text { indeks }\end{array}$ & \multicolumn{2}{|c|}{$0,0-100,0$} \\
\hline & Rata-rata indeks & \multicolumn{2}{|c|}{78,9} \\
\hline \multirow{4}{*}{$\begin{array}{l}\text { Praktek } \\
\text { di luar } \\
\text { rumah }\end{array}$} & Indeks $\leq 50$ (rendah) & 17 & 8,1 \\
\hline & Indeks $>50$ (tinggi) & $\begin{array}{c}19 \\
3\end{array}$ & 91,9 \\
\hline & $\begin{array}{l}\text { Minimum-maksimum } \\
\text { indeks }\end{array}$ & \multicolumn{2}{|c|}{$6,0-75,0$} \\
\hline & Rata-rata indeks & \multicolumn{2}{|c|}{77,3} \\
\hline \multirow{4}{*}{$\begin{array}{l}\text { Praktek } \\
\text { koping }\end{array}$} & Indeks $\leq 50$ (rendah) & 14 & 6,7 \\
\hline & Indeks > 50 (tinggi) & 196 & 93,3 \\
\hline & $\begin{array}{l}\text { Minimum-maksimum } \\
\text { indeks }\end{array}$ & \multicolumn{2}{|c|}{$12,5-100,0$} \\
\hline & Rata-rata indeks & \multicolumn{2}{|c|}{78,3} \\
\hline
\end{tabular}

Keterangan: $n=J u m l a h$ responden; \%=persen

Responden juga melepaskan pakaian dan perlengkapan setelah dari luar rumah sebagai salah satu bentuk praktek koping selama masa pandemi. Hal ini dilakukan agar virus yang menempel di pakaian dan perlengkapan yang dipakai setelah beraktivitas di luar rumah tidak menyebar ke dalam rumah. Responden juga minum lebih banyak vitamin dan lebih banyak tinggal di dalam rumah.

Praktek Koping Psikis di luar Rumah. Responden berusaha menjaga jarak dengan orang lain serta tidak melakukan kegiatan yang melibatkan banyak orang. Karakteristik virus Covid-19 yang dapat menyebar dalam jarak yang dekat membuat praktek menjaga jarak menjadi cara yang cukup banyak dilakukan oleh lansia selama pandemi. Selain menjaga jarak, menghindari kerumunan juga menjadi cara efektif yang bisa dilakukan untuk terlindung dari virus Covid-19. Selain itu, terdapat pula responden yang menggunakan praktek koping dengan berusaha memakai masker dan membawa hand sanitizer jika terpaksa harus bepergian.

\section{Faktor yang Memengaruhi Stres pada Lansia}

Hasil uji pengaruh model faktor-faktor yang memengaruhi tingkat stres pada lansia selama masa pandemi menunjukan nilai koefesien determinasi sebesar 0,443 (Tabel 5). Temuan ini mengindikasikan bahwa sebesar 44,3 persen faktor yang memengaruhi stres dapat 
dijelaskan oleh variabel yang diteliti di dalam model, sedangkan sisanya 55,7 persen dipengaruhi oleh variabel lain yang tidak diteliti dalam penelitian ini. Variabel terbesar yang memengaruhi stres lansia ialah sumber stres. Faktor yang signifikan memengaruhi stres pada lansia selama masa pandemi ialah adalah usia, jenis kelamin, pendidikan, dan sumber stres.

Faktor yang paling besar memengaruhi stres pada lansia ialah stressor. Jumlah stres responden $(\beta=0,469)$ memiliki pengaruh yang positif terhadap stres. Hal ini menunjukan bahwa setiap peningkatan jumlah sumber stres (baik fisik dan psikis) pada lansia sebanyak satu skor indeks akan meningkatkan skor indeks stres sebesar 0,469 poin. Usia responden $(\beta=0,237)$ memiliki pengaruh yang positif terhadap stres (Tabel 5). Hal ini menunjukan bahwa setiap pertambahan usia lansia satu tahun akan meningkatkan skor indeks stres lansia sebesar 0,237.

Tabel 5 Koefesien regresi untuk menganalisis pengaruh karakteristik responden dan sumber stres terhadap jumlah stres lansia $(\mathrm{n}=210)$

\begin{tabular}{|c|c|c|c|}
\hline \multirow{2}{*}{ Variabel } & \multicolumn{3}{|c|}{ Sumber stres } \\
\hline & B & Beta & sig. \\
\hline Konstanta & $-3,841$ & & \\
\hline Usia lansia (tahun) & 0,237 & 0,107 & $0,068^{*}$ \\
\hline $\begin{array}{l}\text { Jenis kelamin } \\
\text { ( } 0=\text { perempuan, } \\
1=\text { laki-laki) }\end{array}$ & $-2,865$ & $-0,095$ & $0,098^{*}$ \\
\hline $\begin{array}{l}\text { Kategori status } \\
\text { pernikahan } \\
\text { ( } 0=\text { janda/duda, } \\
1=\text { menikah) }\end{array}$ & 2,085 & 0,066 & 0,269 \\
\hline $\begin{array}{l}\text { Kategori pendidikan } \\
(0=\text { rendah, } 1=\text { tinggi })\end{array}$ & $-4,793$ & $-0,150$ & $\begin{array}{r}0,052^{*} \\
\text { * }\end{array}$ \\
\hline $\begin{array}{l}\text { Kategori } \\
\text { pendapatan } \\
(0=\text { rendah, } 1=\text { tinggi) }\end{array}$ & -0.591 & $-0,020$ & 0,783 \\
\hline $\begin{array}{l}\text { Sumber Stres (skor } \\
\text { indeks) }\end{array}$ & 0,469 & 0,590 & $\underset{* *}{0,000^{*}}$ \\
\hline $\begin{array}{l}\text { Strategi koping } \\
\text { (skor indeks) }\end{array}$ & $-0,028$ & $-0,021$ & 0,755 \\
\hline $\begin{array}{l}\text { Praktek koping } \\
\text { (skor indeks) }\end{array}$ & 0,038 & 0,040 & 0,567 \\
\hline $\mathrm{R}$ & & 0,464 & \\
\hline Adj. $R^{2}$ & & 0,443 & \\
\hline $\mathrm{F}$ & & 21,752 & \\
\hline sig. Model & & $0,000^{* \star *}$ & \\
\hline df & & 209 & \\
\hline $\mathrm{n}$ & & 210 & \\
\hline
\end{tabular}

Keterangan: ${ }^{* * *}$ signifikan pada $p \leq 0,01 ;{ }^{* *}$ signifikan pada $p$ $\leq 0,05$, *signifikan pada $p \leq 0,1$

Sumber : hasil olahan penelitian
Jenis kelamin $(\beta=-2,865)$ ternyata memiliki pengaruh yang cukup signifikan terhadap stres. Hasil uji regresi menunjukan bahwa skor indeks stres lansia perempuan lebih besar 2,865 poin dibandingkan dengan lansia laki-laki. Tingkat pendidikan responden $(\beta=-4,793)$ memiliki pengaruh yang signifikan secara negatif terhadap stres. Hasil uji menunjukan bahwa skor indeks stres lansia dengan tingkat pendidikan rendah lebih besar 4,793 poin dibandingkan dengan lansia berpendidikan tinggi.

Hasil penelitian ini tidak menemukan pengaruh signifikan status pernikahan, pendapatan, strategi koping, dan praktek koping terhadap stres lansia. Hal ini berarti status pernikahan lansia, pendapatan, strategi koping, dan praktek koping lansia tidak langsung memengaruhi stres lansia. Namun, faktor usia, jenis kelamin, pendidikan, pendapatan, strategi koping, dan praktek koping memengaruhi stres yang dialami lansia.

\section{PEMBAHASAN}

Teori yang digunakan dalam penelitian ini ialah teori model ABCX dengan melihat lansia sebagai bagian dari keluarga guna menganalisis stres dan koping yang dilakukan oleh lansia selama pandemi. Pandemi yang menjadi pemicu stres saat ini mengakibatkan gangguan keseimbangan sehingga lansia sebagai bagian dari sebuah sistem keluarga harus dapat membangun kembali keseimbangan yang selama ini terjaga dalam keluarga agar keluarga tetap dapat berfungsi dengan baik. Rosino (2016) menjelaskan bahwa model $A B C X$ memandang unit keluarga sebagai sistem yang harus bisa menjaga keseimbangan agar keluarga bisa berfungsi dan memberikan materi serta sumberdaya yang memadai untuk anggota keluarganya

Lansia sebagai salah satu kelompok yang rentan terdampak Covid-19 mengalami masalah kesehatan mental selama masa pandemi. Temuan utama peneliti menunjukkan peran penting karakteristik sosial ekonomi dan stressor terhadap kondisi stres lansia di masa pandemi. Hasil ini sejalan penelitian-penelitian sebelumnya yang memperlihatkan adanya pengaruh karakteristik sosial ekonomi terhadap stres (Yovanoff, 2011). Tidak hanya itu, Shanahan et al. (2020) dan Muhamad, Muflikhati, dan Simanjuntak (2019) juga menemukan bahwa usia, pendidikan, dan pendapatan berpengaruh terhadap stres selama pandemi. 
Kondisi pandemi yang menyebabkan ancaman bagi semua orang, khususnya lansia sebagai kategori rentan terinfeksi Covid-19 mengakibatkan lansia mengalami ancaman yang sama semasa pandemi. Hasil riset menunjukkan bahwa selama pandemi, sumber stres lansia dalam penelitian ini mengalami rasa takut tertular oleh virus Covid-19 namun di sisi lain harus sering menahan rasa rindu untuk bertemu dengan anak cucu. Rasa takut terhadap Covid-19 menjadi stressor yang paling utama bagi lansia. Selain itu, lansia juga merasakan kekesalan dan kebosanan karna hanya dapat berdiam diri di rumah, tidak dapat bertemu dengan teman-teman dan mengalami gangguan finansial. Sebagian kecil lansia dalam penelitian ini pun merasakan kesepian dan merasa membawa beban berat di dalam dirinya, bahkan sebagiannya juga mengalami perasaan putus asa. Keadaan ini meningkatkan stres pada lansia. Peneliti lain pun menemukan hal serupa yakni selama pandemi, lansia mengalami gejala depresi, kesepian, pesimisme, kemunduran dalam kognisi, dan gangguan pola tidur (Buenaventura, Ho, \& Lapid, 2020). Hasi peneitian menunjukkan bahwa lansia memikirkan tentang Covid-19 padahal mereka tidak bermaksud untuk memikirkannya. Qiu et al. (2020) juga menemukan bahwa lansia merasakan depresi dan kecemasan selama pandemi. Lansia juga merasakan kesendirian karna tidak ada yang dapat memahaminya, bahkan sebagian kecil diantaranya mengalami reaksi fisik seperti berkeringat, kesulitan bernapas, mual atau jantung berdebar kencang, dan sakit perut. Mazo (2015) menyatakan bahwa gejala stres dapat terlihat dari peningkatan tekanan darah, jantung berdebar kencang, hingga migrain. Selain itu, penelitian lain menguatkan hasil penelitian ini dengan hasil temuan yang menyatakan bahwa beratnya tingkatstres ditentukan oleh ancaman yang berasal dari suatu kejadian (Oktarina, Muflikhati, \& Krisnatuti, 2015).

Temuan penelitian menunjukkan bahwa selama masa pandemi, lansia melakukan strategi koping dengan memperbaiki komunikasi dengan orang serumah dengan banyak bercanda dan melakukan hal-hal yang menyenangkan serta berusaha mencari informasi tentang pengalaman pasien yang berhasil sembuh dari Covid-19. Banyak lansia yang patuh dengan protokol kesehatan yang disarankan oleh pemerintah dengan cara sering mencuci tangan dan melepaskan pakaian dan perlengkapan setelah dari luar rumah sebagai upaya untuk mencegah penularan Covid-19. Sumber daya koping berhubungan dengan nilai-nilai keluarga termasuk di dalamnya sumber daya psikologis seperti harga diri dan sumber daya keluarga sosial dan emosional seperti integrasi keluarga dan kemampuan beradaptasi bersama yang dapat memungkinkan keluarga untuk mengatasi stresor (Rosino, 2016).

Faktor penyebab stres terbesar menurut hasil penelitian ini ialah stressor yang dialami selama pandemi. Artinya, semakin banyak sumber stres yang dimiliki oleh lansia mengakibatkan stres yang dialami oleh lansia juga semakin tinggi. Hal ini sejalan dengan hasil riset Mazo (2015) yang menyatakan bahwa stressor memengaruhi tingkat stres seseorang. Sari, Krisnatuti, dan Yuliati (2015) juga mengemukakan bahwa sumber stres yang tinggi dapat meningkatkan stres. Shanahan et al. (2020) juga menyatakan bahwa stressor yang berkaitan dengan tekanan yang dialami selama pandemi mengakibatkan masalah kesehatan mental. Beberapa stresor yang dialami selama pandemi bisa berupa perubahan gaya hidup, perasaan putus asa, dan tekanan emosional. Bahkan menurut Forbes dan Krueger (2019), gangguan keuangan juga berdampak pada kesehatan mental.

Hasil penelitian menunjukkan bahwa usia memengaruhi stres pada lansia. Stres pada lansia yang lebih tua lebih tinggi dibandingkan dengan stres pada lansia yang lebih muda. Bertambahnya usia menjadi hal yang mengakibatkan lansia menjadi semakin mudah mengalami stres. Hasil temuan ini sejalan dengan temuan peneliti lain yang menyatakan bahwa usia memengaruhi tingkat stres seseorang (Chen, Peng, Xu, \& O-Brien, 2018; Lavretsky \& Newhouse, 2012; Panigrahi \& Dash, 2015; Seangpraw et al., 2019). Seiring dengan pertambahan usia lansia maka semakin banyak keterbatasan fisik, mental dan sosial yang dialami oleh lansiaLansia dengan keterbatasan fisik dan gangguan kognitif mengalami hambatan untuk melakukan aktivitas sosial bersama teman-teman mereka dan mengalami penurunan kualitas dalam membangun hubungan yang penting sehingga dapat meningkatkan stres yang dialami. Kondisi yang serba terbatas ini dapat menjadi pemicu stres bagi lansia. Ahn dan Kim (2015) menyatakan bahwa lansia dengan keterbatasan fisik memiliki resiko yang lebih besar dalam hal depresi.

Temuan lain dari penelitian ini menunjukkan bahwa jenis kelamin memiliki pengaruh terhadap stres lansia. Hasil riset menunjukkan 
bahwa stres yang dialami oleh lansia perempuan lebih besar dibandingkan dengan stres yang dialami oleh lansia laki-laki. Hal ini sejalan dengan hasil temuan peneliti lain yang menunjukkan bahwa perempuan memiliki resiko untuk mengalami stres yang lebih tinggi dibandingkan laki-laki (Agrigoroaei, LeeAttardo, \& Lachman, 2016; Duffy, Twenge, \& Joiner, (2019) 2019; Girgus Girgus, Yang \& Ferri, 2017; Sacco, Bucholz, \& Harrington, 2013; Yan et al., 2018). Duffy, Twenge, dan Joiner (2019) menyatakan bahwa wanita lebih rentan terkena gejala internal dibandingkan dengan laki-laki sehingga menyebabkan stres pada perempuan lebih tinggi. Kim dan Cho (2020) juga menyatakan bahwa virus Covid-19 memengaruhi laki-laki dan wanita secara berbeda karena wanita dianggap memiliki risiko yang lebih tinggi untuk berbagai macam penyakit sehingga memungkinkan wanita mengalami stres yang lebih tinggi.

Hasil penelitian menunjukkan bahwa kategori pendidikan berpengaruh terhadap stres lansia. Responden yang memiliki tingkat pendidikan yang tinggi mengalami kondisi stres yang lebih rendah, sementara responden dengan tingkat pendidikan yang rendah mengalami stres yang lebih tinggi. Lansia yangberpendidikan tinggi dianggap lebih mudah dalam menghadapi masalah dengan status pendidikan yang dimilikinya sehingga ketika menghadapi pandemi, stres yang dialami menjadi lebih rendah. Hasil ini menunjukkan temuan serupa dengan penelitian Sari, Krisnatuti, dan Yuliati (2015) yang mengemukakan bahwa pendidikan berpengaruh terhadap stres. Hal ini juga sesuai dengan temuan peneliti lain yang menyatakan bahwa individu yang memiliki pendidikan yang tinggi cenderung mengalami stres yang lebih rendah (Lunau, Siegrist, Dragano, \& Wahrendorf, 2015). Shanahan et al. (2020) juga menemukan bahwa individu berpendidikan rendah memiliki tingkat stres yang lebih tinggi. Bertambahnya tingkat pendidikan lansia dapat menurunkan stres lansia semasa pandemi. Pendidikan yang tinggi akan memengaruhi strategi koping yang dilakukan oleh seseorang sehingga mereka yang berpendidikan tinggi dapat memiliki pekerjaan yang baik dan kesejahteraan keluarga yang semakin meningkat sehingga mereka dapat mengurangi tingkat stres yang dialami (Sari, Krisnatuti, \& Yuliati, 2015). Lansia dengan pendidikan yang tinggi juga cenderung menggunakan strategi koping yang berfokus pada masalah sehingga masalah yg terjadi bisa segera dicari solusinya. Hasil penelitian Fijianto, Rejeki, dan Aryati (2021) menemukan bahwa tingkat pendidikan berhubungan positif dengan strategi koping yang berfokus pada masalah.

Meskipun status pernikahan, pendapatan, strategi koping, dan praktek koping dalam penelitian ini tidak memiliki pengaruh terhadap stres lansia, hasil riset lain menemukan bahwa lansia yang menikah lebih banyak mengalami stres yang tinggi dan lansia berpendapatan rendah juga mengalami stres yang lebih tinggi. Kim dan Cho (2020) menyatakan bahwa pada individu yang menikah, kekhawatiran mengenai resiko anggota keluarga yang akan tertular menjadi lebih tinggi sehingga mereka yang memiliki keluarga akan lebih berhati-hati untuk mencegah penyakit memengaruhi keluarga mereka. Shanahan et al. (2020) juga menyatakan bahwa individu yang memiliki pendapatan rendah menunjukkan tingkat stres yang lebih tinggi. Hasil penelitian Oktarina, Muflikhati, dan Krisnatuti (2015) juga menyatakan bahwa tingkat stres dipengaruhi oleh pendapatan per kapita per bulan yang mengindikasikan bahwa semakin bertambahnya pendapatan akan semakin menurunkan stres. Rosino (2016) mengungkapkan bahwa strategi koping memiliki pengaruh terhadap tingkat stres. Akan tetapi, pada penelitian ini tidak ditemukan adanya pengaruh yang signifikan dari strategi dan praktek koping terhadap stres sehinggahasil penelitian ini tidak sesuai dengan penelitian Oktarina, Muflikhati, dan Krisnatuti (2015) yang mengemukakan bahwa strategi koping berdampak pada berkurangnya tingkat stres.

\section{SIMPULAN DAN SARAN}

Pandemi Covid-19 yang menjadi krisis bagi lansia memberikan dampak bagi kehidupan lansia secara keseluruhan. Lansia dalam penelitian ini mengalami tingkat stres dengan kategori yang rendah meskipun jumlah stres yang dialami akibat pandemi cukup banyak. Stategi koping yang dilakukan sebagai upaya menghadapi pandemi sangat baik dilakukan oleh lansia dalam penelitian ini. Begitu pula dengan praktek koping yang berkaitan dengan protokol kesehatan yang dianjurkan selama pandemi, juga sangat baik dilakukan oleh lansia. Hal ini menunjukkan sumberdaya yang dimiliki lansia sangat membantu mereka dalam menghadapi stres selama pandemi mengancam. Oleh karenanya, dapat dikatakan lansia dalam penelitian ini berhasil melakukan adaptasi terhadap kondisi pandemi dengan menggunakan sumberdaya yang mereka miliki baik berupa sumberdaya materi maupun 
sumberdaya sosial dan emosi. Nilai yang dianut, kepercayaan dan keyakinan agama yang terangkum dalam strategi dan praktek koping yang dilakukan memberikan interpretasi yang positif terhadap pandemi sehingga akhirnya membantu lansia dalam menghadapi pandemi yang dialami. Hal ini juga diduga berkaitan dengan banyaknya lansia yang berasal dari kategori status pendidikan yang tinggi. Hasil uji pengaruh menunjukkan bahwa usia, jenis kelamin, pendidikan dan stressor berpengaruh terhadap stres lansia semasa pandemi. Temuan ini menegaskan bahwa jumlah stressor memiliki pengaruh yang sangat besar terhadap stres yang dialami oleh lansia.

Keterbatasan yang dialami selama masa pandemi mengakibatkan lansia merasa stres, kesepian, dan rindu untuk berkumpul bersama keluarga dan teman-teman sehingga lansia sangat memerlukan keterlibatan dan dukungan dari keluarga dan lingkungan yang menjadi bagian dari sistem keluarga sehingga stres yang dialami lansia bisa diatasi dengan baik. Pemerintah juga diharapkan dapat mengaktifkan peran Poslansia sebagai counseling center bagi lansia yang mengalami stres selama pandemi dengan melakukan konseling atau pertemuan daring untuk menjadi wadah bagi lansia agar tetap bisa melakukan sosialisasi yang terkendala akibat pandemi. Hasil temuan dalam penelitian ini terbatas pada lansia dengan kategori usia 60 tahun ke atas yang didominasi oleh responden yang berasal dari tingkat pendidikan yang tinggi sehingga perlu dilakukan penelitian lebih lanjut dengan menganalisis faktor-faktor lain dan melibatkan responden keluarga dengan tingkat usia lansia yang bervariasi dan karakteristik sosial ekonomi yang lebih beragam.

\section{DAFTAR PUSTAKA}

Agrigoroaei, S., Lee-Attardo, A., \& Lachman, M. E. (2016). Stress and subjective age: Those with greater financial stress look older. SAGE Journals, 39(10), 1075-1099. doi: $10.1177 / 0164027516658502$.

Ahn, J., \& Kim, B. H. (2015). The relationships between functional limitation, depression, suicidal ideation, and coping in older Korean immigrants. Journal of Immigrant Minority Health, 17(1), 1643-1653. doi: 10.1007/s10903-015-0204-2.

Buenaventura, R. D., Ho, J. B., \& Lapid, M. I. (2020). COVID-19 and mental health of older adults in the Philippines: A perspective from a developing country. International Psychogeriatrics.
32(10),1129-1133.

doi:

$10.1017 / \mathrm{S} 1041610220000757$.

Chen, Y., Peng, Y., Xu, H., \& O'Brien, W. H. (2018). Age differences in stress and coping: Problem-focused strategies mediate the relationship between age and positive affect. The International Journal of Aging and Human Development, 86(4), 347-363.

doi: 10.1177/0091415017720890.

Duffy, M. E., Twenge, J. M., \& Joiner, T. E. (2019). Trends in mood and anxiety symptoms and suicide-related outcomes among U.S. undergraduates, 2007-2018: Evidence from two national surveys. Journal of Adolescent Health, 65(5), 590598.

doi: 10.1016/j.jadohealth.2019.04.033.

Fijianto, D., Rejeki, H., Aryati, D. P. (2021). Hubungan tingkat pendidikan dengan strategi koping warga binaan pemasyarakatan di Lapas Kelas IIB Brebes. Jurnal Keperawatan Muhammadiyah, 6(1), 31-36. Retrieved from http://journal.umsurabaya.ac.id/index.php/JKM/article/view/ 7155.

Forbes, M.K., Krueger, R.F. (2019). The Great Recession and Mental Health in the United States. SAGE Journals: Clinical Psychological Science, 7(5), 900-913 . doi : 10.1177/2167702619859337

Gerst-Emerson, K., \& Jayawardhana, J. (2015). Loneliness as a public health issue: The impact of loneliness on health care utilization among older adults. American Journal of Public Health, 105(5), 10131019. doi: 10.2105/AJPH.2014.302427.

Girgus, J. S., Yang, K., \& Ferri, C. V. (2017). The gender difference in depression: Are older person women at greater risk for depression than older person men? Geriatrics (Basel), 2(4), 35-55. doi: 10.3390/geriatrics2040035.

Huang, Y., Zhao, N. (2020). Chinese mental health burden during the COVID-19 pandemic. Asian Journal of Psychiatry, 51(1), 1-3. doi: 10.1016/j.ajp.2020.102052

Hjelm, I., Handa, S., Hoop, J., \& Palermo, J. (2017). Poverty and perceived stress: Evidence from two unconditional cash transfer programs in Zambia. Zambia CGP and MCP Evaluation Teams, 177(1), 110117. doi: 10.1016/j.socscimed.2017.01.023. 
Ivancevich, J. M., Konopaske, R., \& Matteson, M. T. (2005). Organizational Behavior and Management. New York, US: McGraw-Hill Company, Inc.

Jovanovic, J., Lazaridis, K., \& Stefanovic, V. (2006). Theoretical approaches to problem of occupational stress. Acta Facultatis Medicae Naissensis, 23(3), 163-169. Retrieved from https://publisher.medfak.ni.ac.rs/AFMN_1/ 2006/3-

broj/THEORETICAL\%20APPROACHES\% 20TO\%20PROBLEM\%200F\%200CCUPA TIONAL\%20STRESS.pdf

Jing, G., Xing, L. F., Xiao, H. W., \& Vanljzendoorn, M. H. (2020). Coping with COVID-19: Exposure to COVID-19 and negative impact on livelihood predict elevated mental health problems in chinese adults. International Journal of Environmental Research and Public Health, 17(11), 3857-3876. doi: 10.3390/ijerph17113857.

Jorge, J., Llibre-Guerra, Ivonne, Z., JiménezVelázquez, Juan, J., Llibre-Rodriguez, \& Daisy, A. (2020). The impact of COVID-19 on mental health in the Hispanic Caribbean region. International Psychogeriatrics, 32(10), 1143-1146. doi: $10.1017 / \mathrm{S} 1041610220000848$.

Kim, Y. J., \& Cho, J. H. (2020). Correlation between preventive health behaviors and psycho-social health based on the leisure activities of South Koreans in the COVID19 crisis. International Journal of Environmental Research and Public Health, 17(11), 4066-4075. doi: 10.3390/ijerph17114066.

Komite Penanganan COVID-19 dan Pemulihan Ekonomi Nasional. (2020). Peta Sebaran COVID-19. Retrieved from https://COVID19.go.id/peta-sebaran.

Lai, C.-C., Shih, T.-P., Ko, W.-C., Tang, H.-J., \& Hsueh, P.-R. (2020). Severe acute respiratory syndrome coronavirus 2 (SARS-CoV-2) and coronavirus disease2019 (COVID-19): The epidemic and the challenges. International Journal of Antimicrobial Agents, 55(3), 105.924105.933

doi: 10.1016/j.ijantimicag.2020.105924.

Lavretsky, H., \& Newhouse, P. A. (2012). Stress, inflammation and aging. $A m \mathrm{~J}$ Geriatr Psychiatry, 20(9), 729-733. doi: 10.1097/JGP.0b013e31826573cf.
Lunau, T., Siegrist, J., Dragano, N., \& Wahrendorf, M. (2015). The association between education and work stress: Does the policy context matter?. PLoS One. 10(3), 1-17. doi: 10.1371/journal.pone.0121573.

Lyne, J., Roche, E., Kamali, M., \& Feeney, L. (2020). COVID 19 from the perspective of urban and rural general adult mental health services. Irish Journal of Psychological Medicine, 37(3), 181-186. doi: 10.1017/ipm.2020.62.

Mazo, G. N. (2015). Causes, effects of stress, and the coping mechanism of the bachelor of science in information technology students in a Philippine university. Journal of Education and Learning, 9(1), 71-78. doi: 10.11591/edulearn.v9i1.1295.

Muhamad, L. Y. B., Muflikhati, I., \& Simanjuntak, M. (2019). Religiusitas, dukungan sosial, stres, dan penyesuaian wanita bercerai. Jurnal IImu Keluarga dan Konsumen, 12(3), 194-207. doi: 10.24156/jikk.2019.12.3.194

Oktarina, R., Muflikhati, I., \& Krisnatuti, D. (2015). Sumber stres, strategi koping, dan tingkat stres pada buruh perempuan berstatus menikah dan lajang. Jurnal IImu Keluarga dan Konsumen, 8(3), 133-141. doi: 10.24156/jikk.2015.8.3.133.

Panigrahi, S., \& Dash, B. (2015). Stress and coping strategies among senior citizen in selected old age home, berhampur. Nursing Education and Practice, 1(1), 21$25 . \quad$ Retrieved from https://ramauniversityjournal.com/nursing /pdf_file/21-25.pdf

Perhimpunan Dokter Spesialis Kedokteran Jiwa Indonesia. (2020). 5 bulan pandemi COVID-19 di Indonesia [Infographic]. Retrieved from http://pdskji.org/img_lain/infografik3.jpg

Plagg, B., Engl, A., Piccoliori, G., \& Eisendle, K. (2020). Prolonged social isolation of the older person during COVID-19: Between benefit and damage. Archives of Gerontology and Geriatrics, 89(1), 8687. doi: 10.1016/j.archger.2020.104086.

Puspitawati, H., Sarma, M., Herawati, T., Latifah, M., \& Moeljono, P. (2013). Kumpulan panduan sinergisme keluarga dan sekolah. Bogor, ID: IPB Press.

Reger, M. A., Stanley, I. H., \& Joiner, T. E. (2020). Suicide mortality and coronavirus 
disease 2019 - A perfect storm? JAMA Psychiatry, 77(11), 1093-1094. doi: 10.1001/jamapsychiatry.2020.1060.

Rimnacova, Z., \& Kajanova, A. (2019). Stress and the working poorJanuary 2019. Human Affairs, 29(1), 87-94. doi: 10.1515/humaff-2019-0008.

Rosino, M. (2016). ABC-X model of family stress and coping. The Wiley Blackwell Encyclopedia of Family Studies, First Edition, 1-7. doi: 10.1002/9781119085621.wbefs313.

Sacco, P., Bucholz, K. K., \& Harrington, D. (2013). Gender differences in stressful life events, social support, perceived stress, and alcohol use among older adults: Results from a National Survey. Use \& Misuse, Early Online, 49(4), 456-465. doi: 10.3109/10826084.2013.846379.

Santini, Z. I., Jose, P. E., York, C. E., Koyanagi, A., Nielsen, L., Hinrichsen, C., Meilstrup, C., Madsen K. R., \& Koushede, V. (2020). Social disconnectedness, perceived isolation, and symptoms of depression and anxiety among older Americans (NSHAP): A longitudinal mediation analysis. The Lancet Public Health, 5(1), 62-70. doi: 10.1016/S2468-2667(19)30230-0.

Sari, D. Y., Krisnatuti, D., \& Yuliati, L. N. (2015). Stres ibu dalam mengasuh anak pada keluarga dengan anak pertama berusia di bawah dua tahun. Jurnal IImu Keluarga dan Konsumen, 8(2), 80-87. doi: 10.24156/jikk.2015.8.2.80.

Seangpraw, K., Auttama, N., Kumar, R., Somrongthong, R., Tonchoy, P., \& Panta, P. (2019). Stress and associated risk factors among the older person: a crosssectional study from rural Thailand. F1000 Research 2019, 8, 655. doi: 10.12688/f1000research.17903.1.

Slamet, Y. (1993). Analisis kuantitatif untuk data sosial. Solo, ID: Dabara Publisher.

Shanahan, L., Steinhoff, A., Bechtiger L, Murray, A. L., Nivette, A., Hepp, U., Ribeaud, D., \& Eisner, M. (2020). Emotional distress in young adults during the COVID-19 pandemic: Evidence of risk and resilience from a longitudinal cohort study. Psychological Medicine, 110. doi: $10.1017 / S 003329172000241 X$.

United Nation. (2020). The 17th Goals. Department of Economic and Social
Affairs: Sustainable Development. Retrieved from https://sdgs.un.org/goals.

Usman, M., \& Fahy, S. (2020). Coping with the COVID-19 crisis: An overview of service adaptation and challenges encountered by a rural Psychiatry of Later Life (POLL) team. Irish Journal of Psychological Medicine, 37(1), 1-5. doi: 10.1017/ipm.2020.86.

Wang, C., Pan, R., Wan, X., Tan, Y., Xu, L., Ho, C., \& Ho, R. (2020). Immediate psychological responses and associated factors during the initial stage of the 2019 coronavirus disease (COVID-19) epidemic among the general population in China. Int. J. Environ. Res. Public Health, 17(5), 1729-1753. doi: 10.3390/ijerph17051729.

Weiss, D. S. (2007). The Impact of Event Scale: Revised. In J. P. Wilson, \& T. M. Keane (Eds.), Assessing psychological trauma and PTSD: $A$ practitioner's handbook (2nd ed.). New York, US: Guilford Press.

World Health Organization. (2018). WHO Coronavirus Disease. Retrieved from https://worldhealthorg.shinyapps.io/COVI D/

Xiao, H., Zhang, Y., Kong, D., Li, S., \& Yang, N. (2020). Social capital and sleep quality in individuals who self-isolated for 14 days during the coronavirus disease 2019 (COVID-19) outbreak in January 2020 in China. Med. Sci. Monit., 26(1), 18. doi: 10.12659/MSM.923921.

Xie, Y. N. (1998). A preliminary study of the reliability and validity of the Simplified Coping Style Questionnaire [In Chinese]. Chinese Journal of Clinical Psychology, 6(1), 114-115.

Yahya, F. (2013). Crucial factors affecting stress: A study among undergraduates in Pakistan. International Journal of Asian Social Science, 3(2), 428-442. Retrieved from http://www.aessweb.com/journaldetail.php?id=5007

Yan, I., Dominguez, S., Fisher, D. W., \& Dong, H. (2018). Sex differences in chronic stress responses and alzheimer's disease. Neurobiology of Stress, 8(1), 120-126.

doi: 10.1016/j.ynstr.2018.03.002.

Young, J.K., Jeong, H.C. (2020). Correlation between preventive health behaviors and psycho-social health based on the leisure activities of south koreans in the covid-19 
crisis. Int. J. Environ. Res. Public Health, 17(11), 4066-4076. doi: 10.3390/ijerph17114066

Yovanoff, E. K. (2011). Stress and status: How socioeconomic status affects stress in young adult women (Master's
Thesis) Smith College, Northampton, US. Retrieved from https://scholarworks.smith.edu/theses/1 033/ 